\title{
Effect of Fertigation and Foliar Application of Seaweed's Bio Stimulant on Banana Yield
}

\author{
Edouard Tabet ${ }^{1,2}$, Reem Al-Haf ${ }^{2}$, Chadi Hosri ${ }^{2}$, Zahi Zind ${ }^{3}$, Lina Farah ${ }^{1} \&$ Dalida Darazy ${ }^{2}$ \\ ${ }^{1}$ CRFA: Centre de Recherche et Formation Agricole, Lebanese University, Ghazir, Lebanon \\ ${ }^{2}$ Faculty of Agriculture and Veterinary Medicine, Lebanese University, Beirut, Lebanon \\ ${ }^{3}$ Van Iperen International B V, WESTMAAS, Smidsweg 24-3260 AH OUD-BEIJERLAND, Netherlands \\ Correspondence: Lina Farah, CRFA: Centre de Recherche et Formation Agricole/ Lebanese University, Ghazir, \\ Lebanon. Tel: 961-376-1116.
}

Received: January 15, 2021 Accepted: January 25, 2021 Online Published: January 29, 2021

\begin{abstract}
In order to shed light on the effect of the seaweed Ascophyllum nodosum (L.) bio stimulant on the banana fruit, foliar application (Fo), fertigation(F1) and a mix of both interventions (M) were done during 2018-2019 season on banana plants grown in South Lebanon compared with control (Ctrl). The period between flowering and harvest, the bunch weight, the weight and dimensions of fruit, were measured during the study. The results showed that the shortest period between flowering and harvest was observed on samples treated through foliar application (Fo), less with fertigation and then the mix of both (M). Those treatments were very effective in stimulating the weight of bunch and length of fruit, while a significant increase in the weight of fruit was noticed when both applications were done together $(\mathrm{M})$. All treated modalities showed better performance compared with control. There was no difference in the diameter of fruit between all treatments. Therefore, the application of eco-friendly seaweed-based bio stimulant would be beneficial for the time of harvesting, and the size of banana fruits.
\end{abstract}

Keywords: Ascophyllum nodosum (L.), bio stimulant, banana, yield

\section{Introduction}

Banana (Musa sp.), is an important fruit crop in sub-tropical and tropical countries. It is native to tropical south and Southeast Asia, cultivated in the world in an area of 4.8 million ha with global production of 99.99 million metric tons (Dombale et al., 2018).

Banana cultivation in Lebanon is widespread, in general, in coastal areas and in the south in particular. Export value of Lebanon Bananas, including plantains, fresh or dried was more than 12 million \$ in 2014 (UN, 2014). However, due to Syrian war, the banana exports dropped from 38,000 to 30,000 tons in 2017 (FAO, 2017). Concerning world imports, the import value of bananas in Lebanon including plantains, fresh or dried was $135,060 \$$ in 2014 with an estimated weight of 198 tons (UN, 2014).

Banana farming in Lebanon had been booming. However, in the recent period, because of some climate-related problems, difficulty in the discharge of production, and spread of high levels of diseases with a continuous rise in pesticides' cost, the quality of banana decreased and banana cultivation isn't competitive in the market as before. This caused the orientation of farmers towards other profitable crops (Avocado, Citrus), but they didn't have experience in that. Thus they moved back to banana culturing, and tried to plant more areas to receive higher productivity. Therefore, the aim of our study was to improve the production and the quality of banana culture. It was based on applying the brown algae, Ascophyllum nodosum (L.), as a growth bio stimulant to confirm its effect on the productivity and quality of bananas. By accomplishing these objectives, we would contribute to higher banana land productivity and encouraging farmers to keep on planting bananas, that can promote the evolution of sustainable banana cultivation in Lebanon.

\section{Material and Methods}

This study was carried out during 2018, 2019 on a 130 banana plants (Spanish variety) at Adloun, a coastal village at south Lebanon at $61 \mathrm{~km}$ from Beirut with geographical coordination of elevation: $127 \mathrm{~m}$ above sea level, latitude: $33.41^{\circ} \mathrm{N}$ and longitude: $35.27^{\circ} \mathrm{E}$. The plants were cultivated at spacing $2 \mathrm{~m} \mathrm{x} 3 \mathrm{~m}$. Drip irrigation system was used. All horticultural practices already applied in the orchard, were applied as usually implemented by local farmers. 
The bio stimulant Van Iperen Stim Pure AA produced by Van Iperen is composed mainly from pure seaweed (Ascophyllum nodosum) at 85\%, Amino Acid (6\%), K2O (5\%), and Nitrogen (2\%).

\subsection{Planned Experimental Design}

The plot was divided into four modalities:

Control (Ctrl) by irrigating banana with only water.

Fertigation (F1), the bio stimulant liquid was used through the irrigation system at a dosage of $500 \mathrm{ml}$ per deca $(1000 \mathrm{~m} 2)$. The first application was done ten weeks before flower emergence, followed by a four monthly treatments.

Foliar application (F0), the bio stimulant liquid was sprayed on the leaves at a dosage of $200 \mathrm{ml}$ per deca (1000m2). The first application was done ten weeks before flower emergence, followed by a second one 20 days later.

Mixed (M) application where both fertigation and foliar application where used.

\subsection{Parameters of the Experiment}

The studied parameters were the time between flower emergence and harvest, the bunch weight, and the finger weight and dimensions.

Time between flower emergence and harvest

The time (in days) between flower emergence and harvest for each plot was collected by monitoring the dates of flower emergence and harvesting for each sample, and calculating the time in days between them.

\section{Bunch weight}

The banana bunch weight $(\mathrm{Kg})$ of each sample was measured using a digital balance after they were harvested at bunch maturation stage, when the fingers reached the full mature stage during the season.

\section{Weight of finger}

The finger weight $(\mathrm{g})$ was calculated by dividing the total weight of the bunch on the number of fingers per bunch.

$$
\text { Finger weight }=\frac{\text { Bunch weight } \times 1000}{\text { Number of fingers }}
$$

\section{Dimensions of finger}

The dimensions of finger (length, diameter and perimeter) were measured in $(\mathrm{cm})$ using a measuring tape.

\subsection{Statistical Analysis}

A statistical analysis was performed using One-way ANOVA in SPSS 24.0 software (IBM Corporation, Armonk, New York, USA) and means were compared using Tukey's B and Tukey HSD tests at 5\% level. The results of this study were expressed as means.

\section{Results and Discussion}

\subsection{Time Between Flower Emergence and Harvest}

The average period between flower emergence and harvest for treatments Ctrl, F0, F1 and M was 178.50 days, 126.91 days, 156.83 days and 148.08 days respectively.

According to the obtained results (Table 1), the average period between flowering and harvest in treatments F0 was slightly lower than that in treatments $\mathrm{M}$ and F1 respectively where there was a trend close to significant difference. On the other hand, our results showed that there was an interesting trend between the treatment Ctrl and the two treatments, $\mathrm{M}$ and $\mathrm{F} 1$ at $\mathrm{P}>0.1$ where the average period between flowering and harvest in $\mathrm{M}$ and $\mathrm{F} 1$ was lower than that of the Ctrl. The only clear significant difference was between treatments $\mathrm{F} 0$ and $\mathrm{Ctrl}$ in which $\mathrm{P}=0.005$ where the samples in $\mathrm{F} 0$ clearly needed less time to be harvested after flowering than that of the Ctrl. A shorter interval between flower emergence and harvest was observed in the trial done in West Africa by Van Iperen where the same product was used on banana plants.

These results agreed with the study done by Roshdy (2014), who showed that the time of flowering was significantly advanced when spraying potassium silicate and seaweed on grand naine banana. These findings were also clarified by Soliman et al. (2000) and Neumann and Zur-Nieden (2001), noting that the advancing effect of silicon and seaweed extract on flowering time might be attributed to their essential role in balancing the ratio between carbohydrates and nitrogen in favor of flowering. 
Table 1. Average time between flower and harvest, bunch weigh and finger dimensions

\begin{tabular}{|c|c|c|c|c|c|c|c|}
\hline \multirow[t]{2}{*}{ Treatments } & \multirow{2}{*}{$\begin{array}{l}\text { Number } \\
\text { Of samples }\end{array}$} & \multirow{2}{*}{$\begin{array}{l}\text { Time between flower } \\
\text { emergence and } \\
\text { harvest (day) }\end{array}$} & \multirow{2}{*}{$\begin{array}{l}\text { Bunch } \\
\text { Weight } \\
(\mathrm{Kg})\end{array}$} & \multicolumn{4}{|c|}{ Finger dimensions } \\
\hline & & & & $\begin{array}{l}\text { Weight } \\
\text { (g) }\end{array}$ & $\begin{array}{l}\text { Length } \\
(\mathrm{cm})\end{array}$ & $\begin{array}{l}\text { Diameter } \\
(\mathrm{cm})\end{array}$ & $\begin{array}{l}\text { Perimeter } \\
(\mathrm{cm})\end{array}$ \\
\hline F0 & 12 & $126.9^{\mathrm{a}}$ & $27.2^{\mathrm{b}}$ & $132.0^{\mathrm{ab}}$ & $13.52^{\mathrm{b}}$ & 3.49 & $12.21^{\mathrm{b}}$ \\
\hline M & 12 & $148.1^{\mathrm{ab}}$ & $28.7^{\mathrm{b}}$ & $135.8^{\mathrm{ab}}$ & $13.36^{\mathrm{b}}$ & 3.44 & $11.63^{\mathrm{a}}$ \\
\hline $\mathrm{F} 1$ & 12 & $156.8^{\mathrm{ab}}$ & $28.3^{\mathrm{b}}$ & $133.7^{\mathrm{ab}}$ & $13.38^{\mathrm{b}}$ & 3.48 & $11.65^{\mathrm{a}}$ \\
\hline Ctrl & 6 & $178.5^{\mathrm{b}}$ & $22.5^{\mathrm{a}}$ & $115.8^{\mathrm{a}}$ & $12.68^{\mathrm{a}}$ & 3.48 & $11.58^{\mathrm{a}}$ \\
\hline
\end{tabular}

*In columns the numbers with similar exponent represent the absence of significant difference at $\mathrm{P}>0.05$

\subsection{Bunch Weight}

The results of the weight of bunch for each plot are shown in Table 1. The average bunch weight for treatments Ctrl, F0, F1 and M was $22.45 \mathrm{~kg}, 27.15 \mathrm{~kg}, 28.28 \mathrm{~kg}$, and $28.68 \mathrm{~kg}$ respectively.

Based on the above results (Table 1), the average bunch weight of treatment F0 was slightly lower than that of treatments F1 and M respectively where the difference wasn't significant between them. However, the bunch of samples treated by Van Iperen Stim Pure AA liquid through the 3 types of the mentioned applications were significantly heavier than that of the $\mathrm{Ctrl} \mathrm{P}<0.05$.

The improving effect of seaweed extract on the yield and its attributes came to an agreement with those obtained by Roshdy (2014), where the single application of seaweed extracts was significantly accompanied with improving the bunch weight. According to the study of Eman A. Abd el Moniem et al. (2008), the increase in bunch weight was due to the great benefits of algal extract on amending the plants with their requirements from organic and mineral nutrients.

Indeed, our results confirm that in banana crops, foliar spray application is as effective as the application by root drench. Similar increase in weight has been found with other seaweed extracts (Kumari et al., 2011; Zodape et al., 2011), and on other crops sprayed with A. nodosum extract including cucumber, watermelon and pepper (AbdelMawgoud et al., 2010).

These results were in conformity with those obtained by El-Shamaa (2001), Hosam El-Deen et al. (2001) on Williams Banana, Abd El-Aziz (2002), Abd El-Moniem- Eman and Radwan (2003), Ahmed et al. (2003) and Hammam (2003).

According to the study of Ali et al. (2015), A. nodosum extract conduct a significant increase by $63 \%$ in fruit yields, with $0.5 \%$ of A.nodosum extract. This increase in fruit yield was due to the bio-stimulant and bio-fertilisation effects.

\subsection{Weight of Finger}

The results of weight of finger for each plot are shown in Table 1 .

The average weight of finger for treatments Ctrl, F0, F1 and M was $115.75 \mathrm{~g}, 132.03 \mathrm{~g}, 133.74 \mathrm{~g}$ and $135.75 \mathrm{~g}$ respectively.

The average weight of finger in Ctrl was slightly lower than that of treatments F0 and F1 which showed approached significant difference between the Ctrl and treatments F0 and F1 in which P was approximately 0.1 . On the other side, the average weight of fingers in treatment $\mathrm{M}$ was slightly greater than that of treatments $\mathrm{F} 0$ and $\mathrm{F} 1$ which also showed no significant difference between them in which $\mathrm{P}>0.05$. We can note that the only significant difference appeared between treatments $\mathrm{M}$ and Ctrl, where the average weight of finger treated by both fertigation and foliar application (mix) was significantly higher compared with that of the control. Similar results about other crops were reported by Little and Spann (2010), Neily et al. (2010), Ross and Holden, (2010) and Nahed et al. (2011) where the highest amounts of different fruit yield was recorded from A. nodosum extract usage. Based on the study of Norrie J. (2014), the application of Ascophyllum nodosum (L.) under field conditions, showed 8\% yield increase in tomato trials, $30 \%$ weight gain in pepper trials, $25 \%$ in bananas, $31 \%$ in grapes and $7 \%$ in apples.

Koyama et al. (2012) confirmed that A. nodosum causes the stimulation of vegetative growth in the early stages and promoted reproductive growth in the later stages of crop development, the increased fruit yield is suggested to be partly due to increased translocation of nutrients in the large stems. 
In other crops, some authors noticed an increase in fruit weight sprayed with A. nodosum seaweed extract (Abetz and Young, 1983, Jeannin et al., 1991; Danesh et al., 2012; Bozorgi, 2012) or with extracts from other seaweed species (Khan et al., 2009; Briceno-Dominguez et al., 2014; Satish et al., 2015).

\subsection{Dimensions of Finger}

The dimensions of finger consist of the average length, average diameter and average perimeter.

\subsubsection{Average Length of Finger}

The results for the average length of finger for each plot are shown in Table 1.

The average length of fingers for treatments Ctrl, M, F1 and F0 was $12.68 \mathrm{~cm}, 13.35 \mathrm{~cm}, 13.37 \mathrm{~cm}$, and $13.51 \mathrm{~cm}$, respectively.

According to Table 1, the average length of fingers in $\mathrm{M}$ was slightly lower than that in $\mathrm{F} 1$ and F0 which showed no significant difference between them. We can note that the foliar, fertigation and mix (foliar with fertigation) applications of Van Iperen Stim Pure AA liquid were clearly responsible for the increase in the length of finger in which the average length of finger in Ctrl was significantly lower than that of $\mathrm{F} 0, \mathrm{~F} 1$ and $\mathrm{M}$ at $\mathrm{P}<0.05$.

Similar results about eggplants and different plants were reported by Bozorgi (2012) where the highest fruit length of eggplant was $34.42 \mathrm{~cm}$ recorded from $2 \mathrm{~g} / 1$ of $A$. nodosum extract applied by foliar spraying application.

\subsubsection{Average Diameter of Finger}

The results for the average diameter of finger for each plot are shown in Table1. The average diameter for treatments $\mathrm{M}, \mathrm{F} 1, \mathrm{Ctrl}$, and F0 was $3.44 \mathrm{~cm}, 3.48 \mathrm{~cm}, 3.48 \mathrm{~cm}$, and $3.49 \mathrm{~cm}$ respectively.

The average diameter of finger (Table 1) in treatment $\mathrm{M}$ was slightly lower than that of treatments F1, Ctrl and F0 which showed no significant difference between them at $\mathrm{P}>0.05$. Thus, the application of seaweed bio stimulant has no effect on banana average diameter of fingers.

\subsubsection{Average Perimeter of Finger}

The results for the average perimeter of finger for each plot are shown in Table 1. The average perimeter for treatments Ctrl, M, F1 and F0 was $11.58 \mathrm{~cm}, 11.63 \mathrm{~cm}, 11.65 \mathrm{~cm}$, and $12.21 \mathrm{~cm}$ respectively. The average perimeter (Table 1) in treatment Ctrl was slightly lower than that of treatments $\mathrm{M}$ and F1 which showed no significant difference between them at $\mathrm{P}>0.05$.

\section{Conclusions}

Van Iperen's Ascophyllum nodosum (L.) bio stimulant product used clearly showed effects on reducing period between the banana flowering and harvest time, with a significant increase in bunch weight disregarding the method of treatment (foliar, fertigation or mixed application). Even though we noticed a slight increase in fruit length of $5.83 \%$, no significant correlation was established between the increased weight and the dimensions of the fruit. This leads us to conclude that the average increase in finger weight at $15.57 \%$ is actually more due to an increase in fruit density rather than fruit size. The application of bio stimulant in the Mediterranean coastal area can be economically justified because of increase of yield and financial returns.

\section{References}

Abdel-Mawgoud, A. M. R., Tantaway, A., Hafez, M. M., \& Habib, H. A. M. (2010). Seaweed Extract Improves Growth, Yield and Quality of Different Watermelon Hybrids. Journal of Agriculture and Biological Sciences, 6, 161-168.

Abetz, P., \& Young, C. L. (1983). The Effect of Seaweed Extract Sprays Derived from Ascophyllum Nodosum On Lettuce and Cauliflower Crops. Bot Mar, 26, 487-492. https://doi.org/10.1515/botm.1983.26.10.487

Ahmed, F. F., Abdallah, A. S., \& Sabour-Asmaa, M. T. (2003). Growth and Fruiting of Williams Banana as Affected by Some Antioxidant and Bio-Fertilizer Treatments. Minia Journal of Agricultural Research and Development, 23(1), 51-68.

Ali, N., Farrell, A., Ramsubhag, A., \& Jayaraman, J. (2015). The Effect of Ascophyllum Nodosum Extract on the Growth, Yield and Fruit Quality of Tomato Grown Under Tropical Conditions. Journal of Applied Phycology, 28(2), 1353-1362. https://doi.org/10.1007/s10811-015-0608-3

Bozorgi, H. R. (2012). Effects of Foliar Spraying with Marine Plant Ascophyllum Nodosum Extract and Nano Iron Chelate Fertiliser on Fruit Yield and Several Attributes of Eggplant (Solanum melongena L). ARPN Journal of Agricultural and Biological Science, 7, 357-362. 
Briceno-Dominguez, D., Hernandez-Carmona, G., Moyo, M., Stirk, W., \& Van Staden J. (2014). Plant growth promoting activity of seaweed liquid extracts produced from Macrocystis pyrifera under different $\mathrm{pH}$ and temperature conditions. Journal of Applied Phycology, 26, 2203-2210. https://doi.org/10.1007/s10811-014$0237-2$

Danesh, R. K., Bidarigh, S., Azarpour, E., Moraditochaee, M., \& Bozorgi, H. R. (2012). Study Effects Of Nitrogen Fertiliser Management And Foliar Spraying Of Marine Plant Ascophyllum Nodosum Extract On Yield Of Cucumber (Cucumis sativus L.). International Journal of Agriculture and Crop Sciences, 4, 1492-1495.

Dombale, G. B., Dhutraj, S.V., \& Syed. S. J. (2018). Effect of Foliar Application of Different Nutrients on Maturity Parameters, Finger and Bunch Characteristics and Yield of Banana Cv. Grand Naine. International Journal of Chemical Studies, 6(3), 3651-3654.

El-Shamaa, M. S. (2001). Effect of Bio-Fertilizers on Growth and Yield of Banana Plants (Williams CV.). Assiut Journal of Agricultural Sciences, 32(1), 157-166.

FAO (2004, 2008, 2016, 2017). Retrieved from http://faostat.fao.org/

Hammam, M. S. (2003). Effect of Bio-Fertilization on Growth and Fruiting of Cavendish and Williams Bananas. Egyptian Journal of Horticulture, 30(1-2), 1-159, 67-81.

Hosam El-Deen, A. S., El-Shobaky, M. A., \& Tourky, M. N. F. (2001). Effect of Yeast on Growth, Fruit Quality and Storage Life of Williams Banana. Mansoura University Journal of Agricultural Sciences, 26(7), 44834490.

Jeannin, I., Lescure, J. C., \& Morot-Gaudry, J. F. (1991). The Effects of Aqueous Seaweed Sprays on the Growth of Maize. Bot Mar, 34, 469-473. https://doi.org/10.1515/botm.1991.34.6.469

Khan, W., Rayirath, U. P., Subramanian, S., Jithesh, M. N., Rayorath, P., Hodges, D. M., \& Prithiviraj, B. (2009). Seaweed Extracts as Biostimulants of Plant Growth and Development. Journal of Plant Growth Regulation, 4, 386-399. https://doi.org/10.1007/s00344-009-9103-x

Koyama, R., Bettoni, M. M., Roder, C., De Assis, A. M, Roberto, S. R., \& Mogor, A. F. (2012). Seaweed Extract of Ascophyllum nodosum (L.) on Tomato Yield and Vegetable Development. Journal of Agriculture and Environmental Sciences, 55, 282-287. https://doi.org/10.4322/rca.2012.067

Kumari, R., Kaur, I., \& Bhatnagar, A. K. (2011). Effect of Aqueous Extract of Sargassum Johnstonii Setchell \& Gardner on Growth, Yield and Quality of Lycopersicon esculentum Mill. Journal of Applied Phycology, 23, 623-633. https://doi.org/10.1007/s10811-011-9651-x

Little, H. \& Spann, T. M. (2010). Commercial Extracts of Ascophyllum nodosum(L.) Increase Growth and Improve Water Status of Potted Citrus Rootstocks under Deficit Irrigation. Hort Science. ASHS Annual Conference, August, 2-5.

Mahmoud, Kh. M. H. (2012). Reducing Inorganic N Fertilizer in Balady Mandarin Orchard Through Application of Extracts of Yeast, Seaweed and Farmyard Manure. M.Sc.Thesis Fac. of Agirc. Minia Univ, Egypt.

Merwad, M. M. A. (2011). Effect of Nitrogen Sources, Rates, Some Biostimulants And Antioxidants on Growth And Productivity Of Banana Plants. Ph.D.Thesis Fac.of Agric. Zagazig Univ. Egypt.

Nahed, G., Abdel Aziz, M., Mahgoub, H., \& Siam, H. S. (2011). Growth, Flowering and Chemical Constituents Performance of Amaranthus Tricolor Plants as Influenced by Seaweed (Ascophyllum Nodosum) Extract Application under Salt Stress Conditions. Journal of Applied Sciences Research, 7(11), 1472-1484.

Neily, W., Shishkov, L., Nickerson, S., \& Norrie, J. (2010). Commercial Extract from The Brown Seaweed Ascophyllum Nodosum Improves Early Establishment and Helps Resist Water Stress in Vegetable and Flower Seedlings. Hort Science. ASHS Annual Conference, August, 2-5.

Neumann, D., \& Zur-Nieden, U. (2001). Silicon and Heavy Metal Tolerance of Higher Plants. Phytochemistry, 56, 685-692. https://doi.org/10.1016/S0031-9422(00)00472-6

Norrie, J. (2014). Seaweed Extract and Their Application in Crop Management Programs. Atlantic Canadian Organic Regional Network. Retrieved from http://acornorganic.org/

Oraby, A. A. F. (2013). Partial Replacement of Inorganic Nitrogen Fertilizer by Spraying Some Vitamins, Yeast and Seaweed Extract in Ewaise Mango Orchard under Upper Egypt Conditions. M.Sc. Thesis Fac.of Agric. Minia Univ.Egypt.

Roshdy, Kh. A. (2014). Effect of Spraying Silicon and Seaweed Extract on Growth and Fruiting of Grandnaine 
Banana. Egyptian Journal of Agricultural Research, 92(3), 979-991.

Ross, R., \& Holden, D. (2010). Commercial Extracts of the Brown Seaweed Ascophyllum nodosum Enhance Growth and Yield of Strawberries. HortScience. ASHS Annual Conference, August, 2-5.

Satish, L., Rameshkumar, R., Rathinapriya, P., Pandian, S., Rency, A. S., Sunitha, T., \& Ramesh, M. (2015). Effect of Seaweed Liquid Extracts and Plant Growth Regulators On In Vitro Mass Propagation of Brinjal (Solanum melongena L.) Through Hypocotyl and Leaf Disc Explants. Journal of Applied Phycology, 27, 993-1002. https://doi.org/10.1007/s10811-014-0375-6

Sawsan, A., Omran, Y. A. M. M., \& Abd El-Hamid, H. M. (2010). Enhanced Productivity and Fruit Quality of Flame Seedless Grapevines Treated with Seaweed Extract. Journal of Plant Production, 1(12), 1625-1635.

Soliman, A. I. I., Hussein, M. H., Dessouki, S. A. S., \& Torky Y. (2000). Production of Phytohormones By Using Some Blue Green Algae Used as Soil Inoculants for Rice Fields in Egypt. J. Union Arab Biol., Cairo, 88, 83102. https://doi.org/10.21608/jpp.2010.86606

Subramanian, S., \& Rayirath, U. P. (2009). Seaweed Extracts as Biostimulants of Plant Growth and Development. Journal of Plant Growth Regulation, 1, 386-399. https://doi.org/10.1007/s00344-009-9103-X

United Nations (2014). World investment report 2014.United Nations publication.ISBN 978-92-1-112873-4.

Workman, D. (2019). Bananas Exports by Country. Retrieved from http://www.worldstopexports.com/bananasexports-country/.

Zodape, S. T., Gupta, A., Bhandari, S. C., Rawat, U. S., Chaudhary, D. R., Eswaran, K., \& Chikara, J. (2011). Foliar Application of Seaweed Sap as Biostimulant For Enhancement of Yield and Quality of Tomato (Lycopersicon esculentum Mill). Journal of Scientific and Industrial Research, 70, 215-219.

\section{Copyrights}

Copyright for this article is retained by the author(s), with first publication rights granted to the journal.

This is an open-access article distributed under the terms and conditions of the Creative Commons Attribution license (http://creativecommons.org/licenses/by/4.0/). 